ZOOLOGIA 32 (2): 139-144, April 2015

http://dx.doi.org/10.1590/S1984-46702015000200004

\title{
A new species of Gypona from southern Brazil (Hemiptera: Cicadellidae: Gyponini)
}

\author{
Alexandre Cruz Domahovski ${ }^{1}$, Andressa Paladini ${ }^{1} \&$ Rodney Ramiro Cavichioli ${ }^{1}$
}

\author{
'Departamento de Zoologia, Universidade Federal do Paraná. Caixa Postal 19020, 81531-980 Curitiba, PR, Brazil. \\ E-mail: domahovskiac@yahoo.com.br; andri_bio@yahoo.com.br; cavich@ufpr.br
}

\begin{abstract}
Gypona (Marganalana) masamune sp. nov. is described and illustrated based on specimens from Brazil, state of Paraná. This species can be distinguished from the others of the genus by the following combination of characters: 1) connective with stalk apex oriented anteriorly; 2) style, in lateral view, L-shaped and broader subapically; apex tapered and acute; 3) aedeagus slender, curved dorsally, with long and slender processes arising on each side of shaft near the base, as long as aedeagus shaft; shaft without apical processes. A key to the six subgenera of Gypona is provided.
\end{abstract}

KEY WORDS. Auchenorrhyncha; identification key; Marganalana; Neotropical region; taxonomy.

Gypona is the largest genus of Gyponini. It comprises approximately 300 species included in six subgenera: Elevanosa DeLong, 1977, Gypona Germar, 1821, Marganalana Metcalf, 1949, Obtusana DeLong \& Freytag, 1964, Paragypona DeLong \& Freytag, 1964, and Ruana McKamey, 2006, nomem novum for Urana Coelho \& Nessimian 1991. According to Freytag (2006), the genus was revised by DeLong \& Freytag $(1962,1964)$ and at that time it included 146 species in four subgenera. After 1964, 155 new species and three new subgenera have been described (DeLong \& Martinson 1972, Tesón 1972a, 1972b, DeLong \& Kolbe 1974, 1975, DeLong \& Freytag 1975, DeLong \& Linnavuori 1977, Linnavuori \& DeLong 1977, DeLong 1977, 1979, 1980a, 1980b, 1981, 1982, 1983, DeLong \& Triplehorn 1978, 1979, Delong \& Foster 1981, 1982, Delong \& Wolda 1984 Nessimian \& Coelho 1990a, 1990b, Coelho \& Nessimian 1991, Freytag 2005, 2006). Delong \& Freytag (1964) changed the status of Marganalana to subgenus. FreYTAG (1990) transferred one species to Gypona; the same author, in 1987, elevated the subgenus Carnoseta DeLong, 1981 to genus. The subgenus Urana was renamed by MCKAMEY (2006) as Ruana, because the former was preoccupied. DeLong \& FreYTAG (1964) characterized Gypona as follows: 1) head narrower than pronotum; 2) face broad, short; 3) crown flat, broad, usually longer medially than next to eyes, surface with numerous striae, those between ocelli longitudinal or oblique; 4) anterior margin subfoliaceous or nearly rounded with several transverse striae; 5) pronotum with lateral margins strongly carinate, widest at posterior margin, surface transversely striate; 6) forewing broad, venation normal (not reticulate), appendix well-developed; 7) general color usually green, orange, brown, or black, sometimes patterned; 8) male plates short, usually broader at apex; 9) pygofer simple or bifid at apex; 10) aedeagus stout, recurved, simple, with or without terminal processes.
Based on specimens from Brazil, state of Paraná, a new species of Gypona (Marganalana) is described and illustrated. All specimens were collected by sweeping the substrate, especially grasses in open areas or understories. A key to the six subgenera of Gypona is provided, adapted from DeLong \& Freytag (1964) with addition of Elevanosa and Ruana.

\section{MATERIAL AND METHODS}

The specimens studied are deposited in Coleção de Entomologia Pe. Jesus Santiago Moure, Universidade Federal do Paraná, Curitiba (DZUP) and Museu de Ciências e Tecnologia da Pontifícia Universidade Católica do Rio Grande do Sul, Porto Alegre (MCTP). The terminology follows mainly Young (1968, 1977), except for the head structures, where terms of HAMILTON (1981) are used, as suggested by MejDalani (1998) and leg chaetotaxy, which follows Rakitov (1997). The techniques for preparation of male genital structures follow OMAN (1949) with some modifications described in CAvichIOLI \& TAKIYA (2012). Label data are given inside quotation marks, with a reversed slash ( $\backslash$ ) separating lines on the labels and a semicolon separating labels of a specimen.

\section{TAXONOMY}

\section{Gypona (Marganalana) Metcalf, 1949}

Type-species: Marganalana testacea Metcalf, 1949.

Diagnosis. Body, in dorsal view, elongate. General coloration commonly uniform yellow (green in life), golden or brown, sometimes with color patterns. Pronotum commonly with a rounded black spot behind each eye. Head with crown margin distinct and with several transverse striae. Frontogenal sutures extending only as far as antennal pits. Forewings long,

2015 | Sociedade Brasileira de Zoologia | www.sbzoologia.org.br | www.scielo.br/zool All content of the journal, except where identified, is licensed under a Creative Commons attribution-type BY-NC. 
not reticulate. Pygofer commonly with a bifid apex. Aedeagus without atrial processes.

Distribution. The 186 described species are mainly from South America, approximately one-fourth are Central American and only two are from North America.

\section{Gypona (Marganalana) masamune sp. nov.} Figs 1-19

Diagnosis. General coloration (Figs 18-19) yellow, with inner half of forewings brown. Pygofer (Fig. 6) short, 1.5 times longer than maximum height, with truncated apex. Connective (Fig. 8) with stalk apex oriented anteriorly. Style (Fig. 9), in lateral view, L-shaped, broader subapically; apex tapered, acute. Aedeagus (Figs 10-11) with shaft slender, curved dorsally, with long slender processes arising on each side of shaft near base, as long as aedeagus shaft; without apical processes.

Measurements $(\mathrm{mm})$. Male, total length $6.71(\mathrm{n}=8)$. Female, total length $7.17(n=8)$.

External morphology. Head (Fig. 1), in dorsal view, slightly produced with median length approximately fourtenths of interocular width. Ocelli closer to median line than to eye margins and slightly nearer anterior margin of crown. Head (Fig. 2), in frontal view, with frons slightly depressed medially just below crown margin. Clypeus straight, not inflated, slightly wider apically than basally. Head (Fig. 3), in lateral view, with anterior margin produced, thick and rounded, with transverse striae. Pronotum (Figs 1-3) declivous and transversally striated. Forewing (Fig. 4) approximately 3.2 times longer than wide, without extra crossveins, with R1 present and three closed anteapical cells; appendix well-developed. Foreleg with femur with $\mathrm{AD}, \mathrm{AM}$ and $\mathrm{PD}$ rows reduced, with exception of apical setae AD1, AM1 and PD1; AV and PV rows formed by few and sparse setae, AV row restricted to proximal half and PD row restricted to distal half of femur, consisting of only two setae distant from each other; IC row formed by slightly arched comb of fine setae, beginning at distal half of femur and extending to AM1; foretibia with AV row with short setae on basal half; distal half with four setae two times longer and thicker than basal ones. Hind leg with femoral setal formula 2:2:1; tibia with row AD without intercalary setae between cucullate setae.

Coloration. Head and thorax (Figs 1-3) yellow. Crown (Fig. 1) without maculae. Face (Fig. 2) without maculae. Antennal pedicel black. Pronotum (Fig. 1) with two small black spots behind eyes and brown humeral angles. Mesonotum without maculae. Forewings (Fig. 4) with yellow broad band on costal margin, extending from wing base to second apical cell; clavus, appendix and internal half of apical portion of wing brown. Legs yellow.

Male terminalia. Sternite VIII (Fig. 5) subrectangular, approximately 1.6 times wider than long; lateral corners of posterior margin rounded, middle portion slightly excavated on each side. Pygofer (Fig. 6) short, about 1.5 times longer than maximum height; posteroventral margin slightly more produced than posterodorsal one; apex truncated; macrosetae distributed only near apical portion; valve with conspicuous rounded notch on posterior margin. Subgenital plates (Fig. 7) approximately 3.6 times longer than wide; truncated at apex. Connective (Fig. 8) T-shaped, stalk apex oriented anteriorly; rami approximately as long as stalk. Style (Fig. 8), in dorsal view, with conspicuous truncated outer lobe; in lateral view (Fig. 9), L-shaped, with apical third broader and serrated ventrally; apex tapered, acute and curved dorsally. Aedeagus (Figs 10-11) very long and slender, curved dorsally; dorsal apodeme slender and produced dorsally; a pair of long and slender processes arising on each side of shaft near base, as long as aedeagus shaft; shaft without apical processes, slightly broader apically.

Female terminalia. Sternite VII (Fig. 12) approximately 2.4 times wider than median length; posterior margin with rounded and slightly produced lateral angles, concave on each side of median notch. Internal sternite VIII membranous. Pygofer (Fig. 13) approximately 1.8 times longer than maximum height; apex rounded; macrosetae present on ventroposterior two-thirds. First valvulae (Fig. 14) broad and approximately rectilinear; apical half with dorsal sculptured area strigate; ventral margin with median portion broadly rounded; apex (Fig. 15) narrowed with dorsoapical margin slightly concave. Second valvulae (Fig. 16) with greatest height near middle; dorsal margin with irregular teeth to apical half to apex; apex (Fig. 17) acute with very small teeth.

Material examined. Holotype, male: "S.[São] J.[José] dos

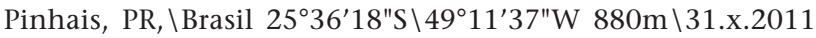
Sweep $\backslash$ A. C. Domahovski leg." [DZUP]. Paratypes: 1 male same holotype data except 05.xi.2011, 2 males same holotype data except 07.xii.2011, 2 males same holotype data except 21.xii.2011, 1 male same holotype data except 22.i.2012, 1 female same holotype data except 24.iii.2012, 1 female same holotype data except 22.vi.2012, 1 male same holotype data except 26.ii.2014, Paladini \& Domahovski leg., 1 female same holotype data except 01.xi.2014, 1 female same holotype data except 15.xi.2014, 1 female same holotype data except 17.i.2015, 2 males and 4 females same holotype data except 24.i.2015 [DZUP]; 1 male and 1 female same holotype data except 24.i.2015 [MCTP].

Etymology. Gypona (M.) masamune (noun in apposition), the name refers to the aedeagus shape that resembles a kind of Japanese long sword called masamune.

Remarks. Gypona (M.) masamune sp. nov. can be easily distinguished from the other Gypona species by the slender aedeagus, with long and slender processes arising from the shaft base, as long as aedeagus shaft. This species is most similar to G. (M.) acuminata DeLong \& Freytag, 1964, described from Colombia, due to the aedeagus with long and slender processes arising on each side of shaft near base and will key out to $G$. (M.) acuminata in the key to Marganalana by DeLong \& FreYtaG (1964). 

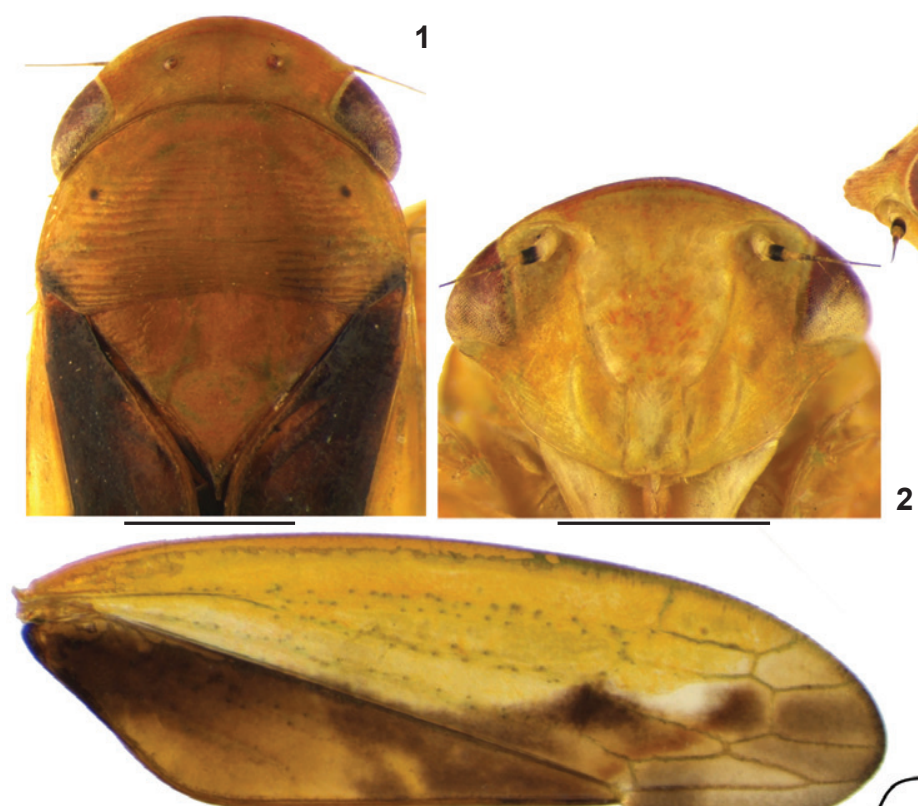

2

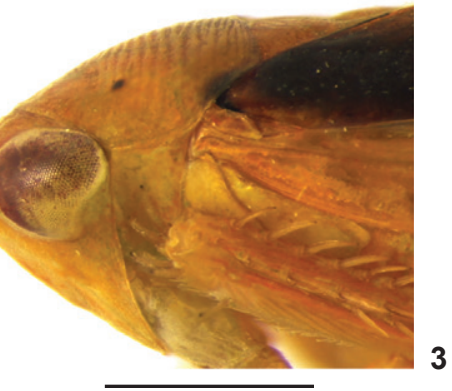

3
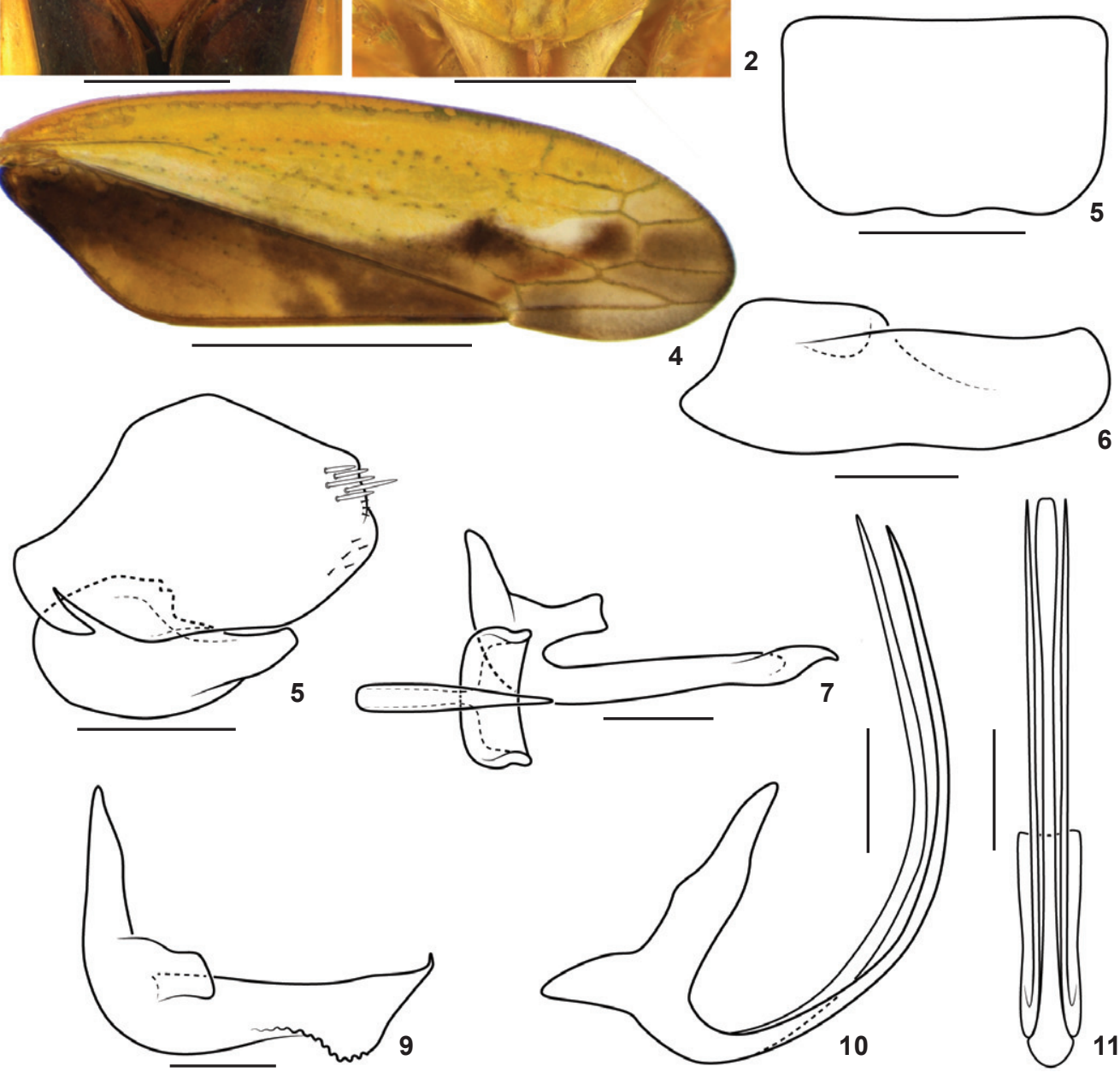

Figures 1-11. Gypona (M) masamune sp. nov., holotype male: (1) head and thorax, dorsal view; (2) head, frontal view; (3) head and thorax, lateral view; (4) forewing, dorsal view; (5) sternite VIII, ventral view; (6) pygofer, valve and subgenital plate, lateral view; (7) subgenital plate, ventral view; (8) style and connective, dorsal view; (9) style, lateral view; (10) aedeagus, lateral view; (11) aedeagus, posterior view. Scale bars: $1-3=1.0 \mathrm{~mm}, 4=2.0 \mathrm{~mm}, 5-6=0.5 \mathrm{~mm}, 7-11=0.25 \mathrm{~mm}$.

According to DeLong \& Freytag (1964), G. (M.) acuminata has the head and pronotum black with a yellow spot surrounding ocelli and extending to base of crown; pronotum with lateral margins yellow and a pair of small yellow spots near anterior margin. The pygofer has a notch on dorsoapical margin and an acute apex. The style has the blade slightly broadened near the middle portion with the apex gradually tapered. The processes that arise from the base of aedeagal shaft are 

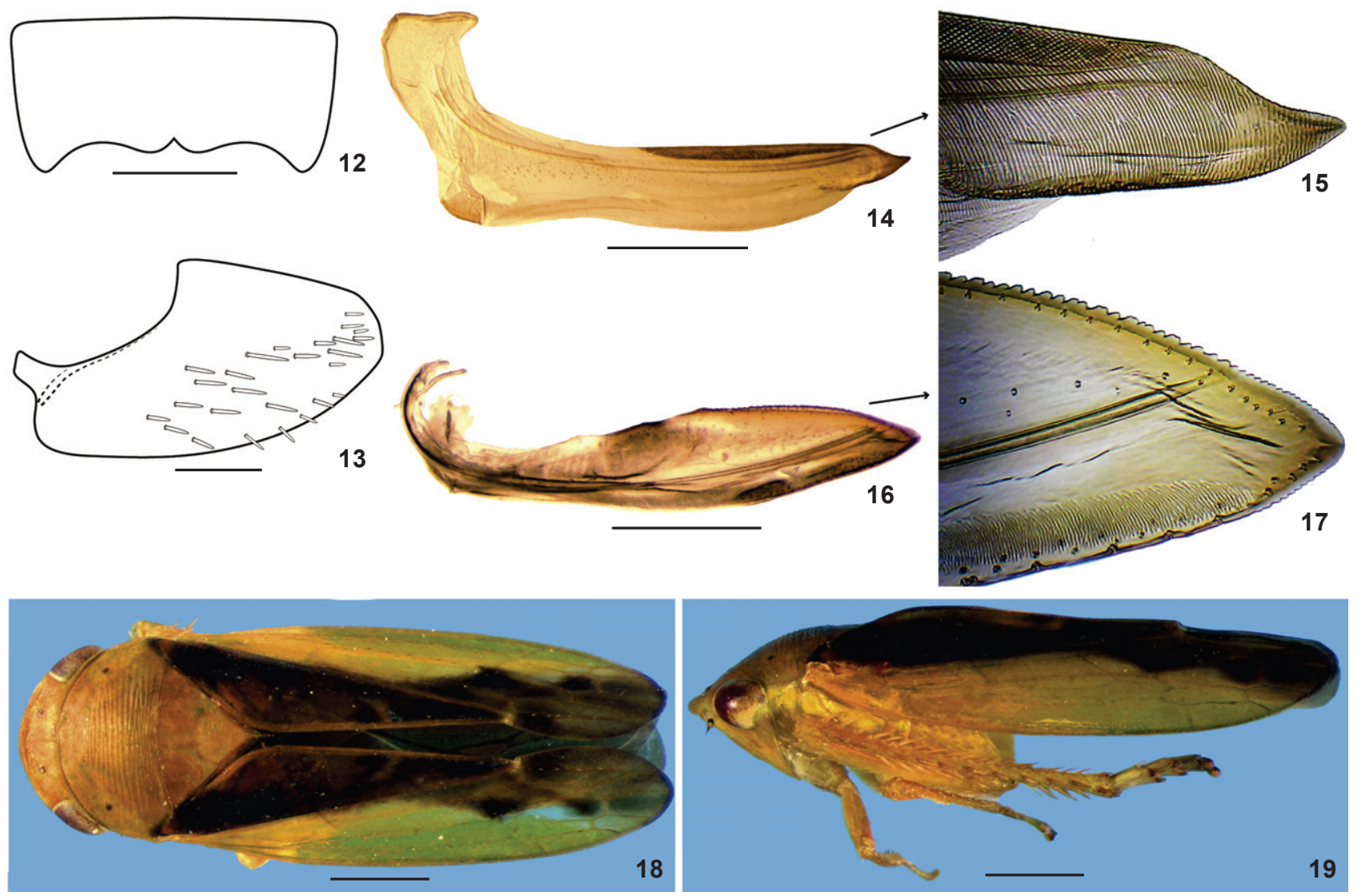

Figures 12-19. (12-17) Paratype, female terminalia: (12) sternite VII, ventral view; (13) pygofer, lateral view; (14) first valvifer and first valvulae, lateral view; (15) first valvulae, apical portion; (16) second valvulae, lateral view; (17) second valvulae, apical portion. (18-19) Habitus: (18) holotype male, dorsal view; (19) holotype male, lateral view. Scale bars: 12-16 = $0.5 \mathrm{~mm}$.

approximately two times longer than the shaft, in posterior view, with apices divergent and, in lateral view, with apex directed posteriorly; the shaft is approximately straight and directed dorsally.

Gypona (M.) masamune sp. nov. differs from G. (M.) acuminata in having the head and pronotum yellow with a small black spot on the pronotum, just behind the eyes. The pygofer differs in lacking a notch on the dorsoapical margin and having the apex truncated. The style differs in having the blade broader at the apical third and apex abruptly tapered with an acute upturned tip. The aedeagus differs in having the basal processes as long as the shaft and parallel in posterior and lateral views, and the shaft curved dorsally.

\section{Key to the subgenera of Gypona}

1. Size large (14-17 $\mathrm{mm})$; frontogenal suture extending to anterior margin of crown (South America) ..... Paragypona

$1^{\prime}$. Size smaller; frontogenal suture extending only as far as antennal pits
2 Head, in dorsal view, with crown margin slightly indented at middle, each side forming a central median lobe which is slightly upturned at apex (Argentina) Elevanosa

2 '. Head, in dorsal view, with crown margin broadly rounded 3

3. Pygofer with conspicuous ventroposterior processes (Brazil) Ruana

3'. Pygofer without ventroposterior processes or, if present, very short

4. Pygofer simple; style commonly with blade short and with truncate apex or nearly so (North and Central America)... Obtusana

4'. Pygofer commonly with a bifid apex; style varying in shape, commonly with acute apex

5. Body, in dorsal view, approximately oval; general coloration commonly with black patterns; head with crown margin thin, smooth, subfoliaceous; forewings short, commonly transparent, sometimes not reaching the pygofer apex of females .. Gypona (Central and South America) 
5'. Body, in dorsal view, elongated; general coloration commonly uniform yellow (green in life); head with crown margin with several transverse striae; forewings long, commonly opaque (North, Central and South America) Marganalana

\section{ACKNOWLEDGEMENTS}

We thank two anonymous reviewers for providing comments and corrections on a draft of this paper. The third author is a research fellow from Conselho Nacional de Desenvolvimento Científico e Tecnológico (process 303.127/2010-4). This research was partially funded by PROTAX/CNPq with research grant to RRC (process 561.298/2010-6) and fellowships to ACD and AP (processes 102184/2013-5 and 150163/2013-4). This paper is the contribution number 1924 of the Departamento de Zoologia, Universidade Federal do Paraná.

\section{LITERATURE CITED}

Cavichioli RR, Takiya DM (2012) Description of a new species of Wolfniana and new records of Rotigonalia (Hemiptera: Cicadellidae: Cicadellinae) from the state of Amazonas, Brazil. Zoologia 29(1): 85-88. doi: 10.1590/S1984-46702012000100011

Coelho LBN, Nessimian JL (1991) Descrição de duas novas espécies e de um novo subgênero de Gypona Germar (Homoptera, Cicadellidae, Gyponinae). Revista Brasileira de Biologia 51(3): 555-559.

DeLong DM (1977) A new subgenus Elevanosa, and new species of Gypona (Homoptera: Cicadellidae). Entomological News 81(1/2): 37-38.

DeLong DM (1979) New species of Gypona and Polana (Homoptera: Cicadellidae: Gyponinae) from Central and South America. Brenesia 16: 151-158.

DeLong DM (1980a) New species of Central and South American Gypona (Homoptera: Cicadellidae). Brenesia 17: 215-250.

DeLong DM (1980b) New species of Gypona (Homoptera, Cicadellidae, Gyponinae) from Central and South America. Revista Peruana de Entomologia 23(1): 59-62.

DeLong DM (1981) New Species of Gypona, Gyponinae (Homoptera, Cicadellidae) with description of a new subgenus. Proceedings of the Entomological Society of Washington 83(3): 505-511.

DeLong DM (1982) New Species of Central and South American Gypona (Homoptera: Cicadellidae). Entomotaxonomia 6(4): 279-286.

DeLong DM (1983) New species of Gypona (Homoptera: Cicadellidae: Gyponinae) from Mexico, Jamaica, Colombia, and Chile. Ohio Journal of Science 83(3): 142-144.

DeLong DM, Foster DR (1981) Six new species of Bolivian Gypona (Homoptera: Cicadellidae). Entomological News 92(4): 141-146.

DeLong DM, Foster DR (1982) New Species of Bolivian Gyponinae (Homoptera, Cicadellidae). Entomological News
93(4): 114-118.

Delong DM, Freytag PH (1962) Studies of the Gyponini (Homoptera: Cicadellidae): The Gypona glauca (Fabricius) complex. Bulletin of the Brooklyn Entomological Society 57(4): 109-131.

DeLong DM, Freytag PH (1964) Four Genera of the World Gyponinae: A synopsis of the Genera Gypona, Gyponana, Rugosana and Reticana. Bulletin of the Ohio Biological Survey, New Series II, (3): 1-227.

DeLong DM, Freytag PH (1975) Studies of the Gyponinae (Homoptera: Cicadellidae) fourteen new species of Central and South America Gypona. Journal of the Kansas Entomological Society 48(3): 308-318.

DeLong DM, Kolbe AB (1974) Studies of the Gyponinae (Homoptera: Cicadellidae) four new species of Gypona from Panama. Journal of the Kansas Entomological Society 47(4): 523-526.

DeLong DM, Kolbe AB (1975) Studies of the Gyponinae: six new species of South American Gypona (Homoptera: Cicadellidae). Journal of the Kansas Entomological Society 48(2): 201-205.

DeLong DM, Linnavuori R (1977) Studies of the Gyponinae: seven new species of Gypona from Central and South America. Journal of the Kansas Entomological Society 50(3): 335-341.

DeLong DM, Martinson C (1972) Studies of the Gyponinae (Homoptera: Cicadellidae) - Fourteen new species of Gypona from Central and South America. The Ohio Journal of Science 72(3): 161-170.

Delong DM, Triplehorn BW (1978) Four new species of Gyponinae (Homoptera: Cicadellidae) from Paraguay. Entomological News 89(7/8): 179-182.

DeLong DM, Triplehorn BW (1979) New species of Gyponinae (Homoptera: Cicadellidae) from Peru. Brenesia 16: 171-188.

Delong DM, Wolda H (1984) New Panamanian Gyponine leafhoppers (Homoptera: Cicadellidae) belonging to the genera Hecalapona, Gypona and Gyponana. Uttar Pradesh Journal of Zoology 4(2): 135-144.

FreYtAg PH (1987) Two New Genera, Brevisana and Minimana, and Four New Species of Gyponinae (Homoptera: Cicadellidae). The Ohio Journal of Science 87(1): 33-35.

Freytag PH (1990) A new genus Nancyana and nine new species with a review of the related genus Rhogosana (Homoptera: Cicadellidae). Proceedings of the Entomological Society of Washington 92(3): 530-537.

Freytag PH (2005) The Gyponinae of Hispaniola (Hemiptera: Cicadellidae). Journal of the Kansas Entomological Society 78(4): 322-340.

Freytag PH (2006) Six new species of Gypona from Colombia (Hemiptera: Cicadellidae: Gyponinae). Entomological News 117(5): 503-510.

Hamilton KGA (1981) Morphology and evolution of the rhynchotan head (Insecta: Hemiptera, Homoptera). Cana- 
dian Entomologist 113: 953-974.

Linnavuori R, DeLong DM (1977) The leafhoppers (Homoptera: Cicadellidae) known from Chile. Brenesia 12/13: 163-267.

McKamey SH (2006) Further new genus-group names in the Cicadellidae (Hemiptera). Proceedings of the Entomological Society of Washington 108(3): 502-510.

Mejdalani G (1998) Morfologia externa dos Cicadellinae (Homoptera, Cicadellidae): comparação entre Versigonalia ruficauda (Walker) (Cicadellini) e Tretogonia cribrata Melichar (Proconiini), com notas sobre outras espécies e análise da terminologia. Revista Brasileira de Zoologia 15: 451-544. doi: 10.1590/S0101-81751998000200015

Nessimian JL, Coelho LBN (1990a) Nova espécie de Gypona Germar, 1921 (Homoptera, Cicadellidae, Gyponinae). Revista Brasileira de Entomologia 34(3): 655-656.

Nessimian JL, Coelho LBN (1990b) Nova espécie de Gypona Germar (Homoptera, Cicadellidae) do Brasil. Revista Brasileira de Entomologia 34(4): 785-787.

OMAN PW (1949) The Nearctic leafhoppers (Homoptera:
Cicadellidae). A generic classification and check list. Memoirs of the Entomological Society of Washington 3: $1-253$.

Rakitov RA (1997) On differentiation of the cicadellid leg chaetotaxy (Homoptera: Auchenorrhyncha: Membracoidea). Russian Entomological Journal 6: 7-27.

Tesón A (1972a) Notas sobre giponinos neotropicales. II. (Homoptera, Cicadellidae). Revista de la Sociedad Entomológica Argentina 34(1/2): 57-60.

TESón A (1972b) Notas sobre giponinos neotropicales. III. (Homoptera, Cicadellidae). Revista de la Sociedad Entomológica Argentina 34(1/2): 131-135.

Young DA (1968) Taxonomic study of the Cicadellinae (Homoptera: Cicadellidae), Part 1, Proconiini. Bulletin of the United States National Museum 261: 1-287.

Young DA (1977) Taxonomic study of the Cicadellinae (Homoptera: Cicadellidae), Part 2, New World Cicadellini and the genus Cicadella. Technical Bulletin of the North Carolina Agricultural Experiment Station 239: 1-1135.

Submitted: 19 December 2014

Received in revised form: 19 February 2015

Accepted: 28 February 2015

Editorial responsibility: Gabriel L.F. Mejdalani 